\title{
Effects of freezing intensity on soil solution nitrogen and microbial biomass nitrogen in an alpine grassland ecosystem on the Tibetan Plateau, China
}

\author{
YANG Zhaoping $^{1}$, GAO Jixi $^{2 *}$, YANG Meng ${ }^{1}$, SUN Zhizhong ${ }^{3}$ \\ ${ }^{1}$ Jiangsu Collaborative Innovation Center of Atmospheric Environment and Equipment Technology, School of Environmental \\ Science and Engineering, Nanjing University of Information Science \& Technology, Nanjing 210044, China; \\ ${ }^{2}$ Nanjing Institute of Environmental Sciences, Ministry of Environmental Protection, Nanjing 210042, China; \\ ${ }^{3}$ State Key Laboratory of Frozen Soil Engineering, Cold and Arid Regions Environmental and Engineering Research Institute, \\ Chinese Academy of Sciences, Lanzhou 730000, China
}

\begin{abstract}
The change of freeze-thaw pattern of the Tibetan Plateau under climate warming is bound to have a profound impact on the soil process of alpine grassland ecosystem; however, the research on the impact of the freeze-thaw action on nitrogen processes of the alpine grassland ecosystem on the Tibetan Plateau has not yet attracted much attention. In this study, the impact of the freezing strength on the soil nitrogen components of alpine grassland on the Tibetan Plateau was studied through laboratory freeze-thaw simulation experiments. The $0-10 \mathrm{~cm}$ topsoil was collected from the alpine marsh meadow and alpine meadow in the permafrost region of Beilu River. In the experiment, the soil samples were cultivated at $-10^{\circ} \mathrm{C},-7^{\circ} \mathrm{C},-5^{\circ} \mathrm{C},-3^{\circ} \mathrm{C}$ and $-1^{\circ} \mathrm{C}$, respectively for three days and then thawed at $2^{\circ} \mathrm{C}$ for one day. The results showed that after the freeze-thaw process, the soil microbial biomass nitrogen significantly decreased while the dissolved organic nitrogen and inorganic nitrogen significantly increased. When the freezing temperature was below $-7^{\circ} \mathrm{C}$, there was no significant difference between the content of nitrogen components, which implied a change of each nitrogen component might have a response threshold toward the freezing temperature. As the freeze-thaw process can lead to the risk of nitrogen loss in the alpine grassland ecosystem, more attention should be paid to the response of the soil nitrogen cycle of alpine grasslands on the Tibetan Plateau to the freeze-thaw process.
\end{abstract}

Keywords: freezing temperature; microbial biomass nitrogen; dissolved organic nitrogen; inorganic nitrogen; alpine grassland; Tibetan Plateau

Citation: YANG Zhaoping, GAO Jixi, YANG Meng, SUN Zhizhong. 2016. Effects of freezing intensity on soil solution nitrogen and microbial biomass nitrogen in an alpine grassland ecosystems on the Tibetan Plateau, China. Journal of Arid Land, 8(5): 749-759. doi: 10.1007/s40333-016-0012-0

Global warming and the corresponding environmental change will have a strong influence on the high-altitude ecosystem in this century (IPCC, 2007). The warming can reduce the thickness of snow cover and even make the snow thaw, resulting in the augmentation of soil temperature variability in winter (Isard and Schaetzl, 1998; Mellander et al., 2007). Along with the occurrence of more and more extreme and variable climate events (Easterling et al., 2000; IPCC, 2007), climate warming will alter the snow thickness and melting pattern in the Arctic (Grogan and Jonasson, 2003) and alpine regions (Brooks and Williams, 1999; Kaste et al., 2008), thereby

${ }^{*}$ Corresponding author: GAO Jixi (E-mail: gjx@nies.org)

Received 2015-12-21; revised 2016-04-08; accepted 2016-04-21

(C) Xinjiang Institute of Ecology and Geography, Chinese Academy of Sciences, Science Press and Springer-Verlag Berlin Heidelberg 2016 
affecting the soil freeze-thaw process (Henry, 2008).

Studies have shown that soil respiration and $\mathrm{N}$ mineralization are still continuing in the non-freezing water film when the soil temperature is below $0^{\circ} \mathrm{C}$ (Panikov et al., 2006), thus soil respiration and $\mathrm{N}$ mineralization in winter cannot be ignored on a long time scale (Grogan et al., 2004; Campbell et al., 2005; Kielland et al., 2006; Monson et al., 2006). The soil freeze-thaw action can change the physical structure of the soil, influence microbial activity and community composition (Schadt et al., 2003; Lipson and Schmidt, 2004; Six et al., 2004; Sjursen et al., 2005) as well as promote the loss of ecosystem $\mathrm{C}$ and nutrient elements with the emission of runoff (Deluca et al., 1992; Wang and Bettany, 1993; Ron Vaz et al., 1994) or trace gas (Chen et al., 1995; Chang and Hao, 2001), resulting in the reduction of primary productivity. Under the background of global warming, the changes in the soil freeze-thaw process and its impact on the ecosystem have attracted widespread attention (Nielsen et al., 2001).

The Tibetan Plateau, which is known as a climate change pacemaker or warning area, is very sensitive to global climate change. Most of the Tibetan Plateau has experienced statistically significant warming since the mid-1950s, especially in winter. The linear rate of temperature increase over the Tibetan Plateau was about $0.16^{\circ} \mathrm{C} / 10 \mathrm{a}$ for the annual mean and $0.32^{\circ} \mathrm{C} / 10 \mathrm{a}$ for the winter mean, exceeding those for the Northern Hemisphere and the same latitudinal zone in the same period (Liu and Chen, 2000). Meanwhile, the alpine grassland is generally threatened by drought and desertification, such as the grassland degradation at the Three-River Source area (Liu et al., 2008) and the degradation and desertification of grassland on the Zoige Plateau (Dong et al., 2010). Under the background of climate change, the alpine grassland of the Tibetan Plateau will inevitably lead to advanced soil thaw and the increase of freeze-thaw frequency due to the temperature rise, land cover change (vegetation degradation and desertification) and moisture change (drought). The change of freeze-thaw pattern in the Tibetan Plateau is bound to have a profound impact on the soil process of the alpine grassland ecosystem; however, the research on the impact of freeze-thaw action on the $\mathrm{N}$ process of the alpine grassland ecosystem on the Tibetan Plateau has not yet attracted much attention.

The freezing intensity plays an important role in determining the quantity and chemical form of the available nutrients in soil after the freeze-thaw action (Edwards and Cresser, 1992; Herrmann and Witter, 2002). In this study, the impact of the freezing temperature change on the soil nitrogen dynamics of the alpine grassland ecosystem on the Tibetan Plateau was researched through freeze-thaw simulation experiments. The research results will help to understand the soil ecological process of the alpine grassland ecosystem during non-growing seasons and provide the basis for predicting the response of the alpine grassland ecosystem on the Tibetan Plateau to climate change.

\section{Materials and methods}

\subsection{Study area}

The study area belongs to the high-cold climate zone of the Tibetan Plateau, which is located in the permafrost region of the Beilu River at the source of the Yangtze River $\left(34^{\circ} 49^{\prime} 40^{\prime \prime} \mathrm{N}\right.$, $92^{\circ} 56^{\prime} 02^{\prime \prime} \mathrm{E} ; 4,630 \mathrm{~m}$ asl). The average annual precipitation is $290.9 \mathrm{~mm}$, concentrated in June to August, which occupies more than $80 \%$ of the precipitation for the year. The monthly average air temperature is below $0^{\circ} \mathrm{C}$ except in the growing season, and the annual mean temperature is $-5.2^{\circ} \mathrm{C}$. The average annual potential evaporation capacity is $1,316.9 \mathrm{~mm}$ and the annual average wind speed is $4.1 \mathrm{~m} / \mathrm{s}$. The thickness of the permafrost active layer is generally $2-3 \mathrm{~m}$ with a maximum value of $3.4 \mathrm{~m}$ and minimum value of $1.7 \mathrm{~m}$, and the ground temperature of continuous permafrost rages from $-3.0^{\circ} \mathrm{C}$ to $-1.0^{\circ} \mathrm{C}$. The soil types are mainly alpine meadow soil, alpine shrub meadow soil and alpine marsh meadow soil, among which the alpine meadow soil is most widespread with slow decomposition and obvious accumulation of soil organic matter. The ecosystem types include alpine meadow, alpine marsh meadow, alpine steppe, etc. Cyperaceous Kobresia dominates the meadow plants and the Poaceae and Asteraceae dominate the steppe 
plants.

Soils were sampled from alpine marsh meadow and alpine meadow. Alpine marsh meadow mainly takes Kobresia tibetica as the constructive species with $85 \%-90 \%$ of coverage and the alpine meadow mainly includes Kobresia pygmaea, K. humilis and K. capilifolia with more than $95 \%$ of coverage (Table 1). For each ecosystem type, three $25 \mathrm{~cm} \times 25 \mathrm{~cm}$ squares with an interval of at least $10 \mathrm{~m}$ were selected. In each plot, after the removal of surface litter and aboveground vegetation, surface soil $(0-10 \mathrm{~cm})$ was sampled at the end of July, the period of vigorous growth on the Tibetan Plateau. Three soil cores were sampled to measure the bulk density in each plot with a volumetric ring. Soil samples were put into plastic bags and quickly taken back to the laboratory. Following removal of visible root material by hand picking, each soil sample was sieved with a 2-mm mesh and divided into two sub-samples. One sub-sample was stored at $4^{\circ} \mathrm{C}$ for use in the laboratory incubation experiment and the other was naturally air-dried for determination of physical-chemical properties of soil.

\subsection{Experimental design}

Before the freeze-thaw treatment, the soil samples were cultivated at a constant temperature of $11^{\circ} \mathrm{C}$ (the average temperature in July) for four days. According to the monitoring results of the ground temperature of the sampling sites, the freezing temperatures were set at $-10^{\circ} \mathrm{C},-7^{\circ} \mathrm{C}$, $-5^{\circ} \mathrm{C},-3^{\circ} \mathrm{C}$ and $-1^{\circ} \mathrm{C}$, respectively. The homogenized soil samples (approximately $100 \mathrm{~g}$ air-dry soil) were put into $500 \mathrm{~mL}$ culture flasks, cultivated at each freezing temperature for three days and then thawed at $2{ }^{\circ} \mathrm{C}$ for one day. We maintained untreated soil samples (U) at $11^{\circ} \mathrm{C}$ for the duration of the experiment. Each treatment was repeated three times. For preventing water evaporation, we sealed the bottles with plastic wrap with ventilation holes on it so as to produce aerobic cultivation.

\subsection{Methods}

The $\mathrm{N}_{-} \mathrm{NH}_{4}{ }^{+}, \mathrm{N}_{-} \mathrm{NO}_{3}{ }^{-}$, dissolved organic nitrogen (DON) and microbial biomass nitrogen (MBN) in the soil were measured. The $\mathrm{N}_{-} \mathrm{NH}_{4}{ }^{+}$and $\mathrm{N}-\mathrm{NO}_{3}{ }^{-}$were extracted with $75 \mathrm{~mL} 0.02 \mathrm{~mol} / \mathrm{L} \mathrm{KCl}$ using a 1:5 soil to extractant $(\mathrm{w} / \mathrm{v})$ ratio on a reciprocal shaker for $1 \mathrm{~h}$. The extracts were filtered

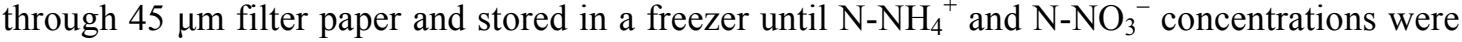
analyzed on a flow injection analyzer (FIAstar 5000 Analyzer, Foss, Denmark). The filtrate used for the measurement of inorganic nitrogen above was filtered again using a $0.45-\mu \mathrm{m}$ filter membrane. The content of total soluble nitrogen in the filtrate was measured by the potassium persulfate oxidation method (Yang et al., 2005, 2007). After $0.5 \mathrm{~h}$ oxidation in a pressure cooker, total soluble nitrogen was measured using ultraviolet spectrophotometry. Microbial biomass was analyzed using the fumigation-extraction technique (Brookes et al., 1985). Five-gram soil samples were extracted in $0.5 \mathrm{M} \mathrm{K}_{2} \mathrm{SO}_{4}$ for $1 \mathrm{~h}$. Meanwhile, another set of 5-g sub-samples was fumigated with ethanol-free chloroform for $24 \mathrm{~h}$, and then extracted in a similar manner. Both the unfumigated and fumigated soil extracts were filtered through Whatman GF/D filters. The difference between the concentrations in the fumigated and unfumigated extracts was used to estimate the amount of $\mathrm{N}$ in the microbial biomass. For accounting for incomplete extractability, we used a correction factor of 0.54 for microbial $\mathrm{N}$ (Li et al., 2010). The potassium dichromate method was adopted to measure the soil organic matter.

\subsection{Statistical analyses}

We used one-way analysis of variance (ANOVA) to assess the difference in soil nitrogen fractions content between freezing temperatures. We tested homogeneity of variances among the data in the freeze-thaw treatment using Levene's test. We used least-significant-difference (LSD) tests for multiple comparisons when the variances were homogeneous; otherwise, we used Tamhane's T2 test. We used unitary linear regression analysis to evaluate the relationships between the content of microbial biomass nitrogen and dissolved organic nitrogen. In all analyses, when $P<0.05$, differences and correlations were considered statistically significant. All data analyses were conducted using version 13.0 of the SPSS software (SPSS Inc., Chicago, IL, USA). 


\section{Results}

\subsection{Soil physical-chemical properties}

The soil clay content of alpine marsh meadow soil was $8.28 \%$ and its soil silt content was $15.07 \%$, both of which were higher than those of alpine meadow soil. The soil bulk density of alpine meadow was $1.13 \mathrm{~g} / \mathrm{cm}^{3}$, greater than that of alpine marsh meadow soil, which was $0.77 \mathrm{~g} / \mathrm{cm}^{3}$ (Table 1). The $\mathrm{pH}$ value of alpine marsh meadow soil was 7.46 and that of alpine meadow soil was 7.52, which indicated that the soil at the sampling sites was weakly alkaline. The soil organic carbon (SOC), total nitrogen (TN) and total phosphorus (TP) contents of alpine meadow soil were $14.53,1.41$ and $0.39 \mathrm{~g} / \mathrm{kg}$, respectively and those of alpine marsh meadow soil were $51.24,4.02$ and $0.51 \mathrm{~g} / \mathrm{kg}$, respectively, which meant the soil nutrient of alpine marsh meadow was better than that of alpine meadow.

Table 1 soil physical-chemical properties at the $0-10 \mathrm{~cm}$ soil depth

\begin{tabular}{|c|c|c|c|c|c|c|c|c|}
\hline \multirow{2}{*}{ Ecosystem type } & Clay & Silt & Sand & \multirow{2}{*}{$\begin{array}{l}\text { Bulk density } \\
\qquad\left(\mathrm{g} / \mathrm{cm}^{3}\right)\end{array}$} & SOC & $\mathrm{TN}$ & $\mathrm{TP}$ & \multirow{2}{*}{$\mathrm{pH}$} \\
\hline & & $(\%)$ & & & \multicolumn{3}{|c|}{$(\mathrm{g} / \mathrm{kg})$} & \\
\hline AMM & 8.28 & 15.07 & 76.65 & 0.77 & 51.24 & 4.02 & 7.46 & 0.51 \\
\hline $\mathrm{AM}$ & 7.64 & 14.13 & 78.23 & 1.13 & 14.53 & 1.41 & 7.52 & 0.39 \\
\hline
\end{tabular}

Note: Values are means $(n=3)$. AMM, alpine marsh meadow; AM, alpine meadow; SOC, soil organic carbon; TN, total nitrogen; TP, total phosphorus.

\subsection{Effect of freezing intensity on $\mathrm{MBN}$ content}

For untreated soil samples, the MBN content of alpine marsh meadow soil was $36.68 \mathrm{mg} / \mathrm{kg}$ and that of alpine meadow soil was $21.51 \mathrm{mg} / \mathrm{kg}$. Freeze-thaw treatment had a significant impact on the MBN of alpine grassland soil (Fig. 1). After freeze-thaw treatment at $-1{ }^{\circ} \mathrm{C}$, the $\mathrm{MBN}$ of alpine marsh meadow soil decreased by $11.13 \mathrm{mg} / \mathrm{kg}$ and that of alpine meadow soil decreased by $15.14 \mathrm{mg} / \mathrm{kg}$, both of which decreased significantly. The MBN contents of alpine marsh meadow soil decreased significantly after freeze-thaw treatments from $-3^{\circ} \mathrm{C}$ to $-7^{\circ} \mathrm{C}$, while there was no significant difference between the MBN contents of alpine marsh meadow soil after freeze-thaw treatments from $-7^{\circ} \mathrm{C}$ to $-10^{\circ} \mathrm{C}$. The $\mathrm{MBN}$ content of alpine meadow soil had the same change trend as that of alpine marsh meadow soil.

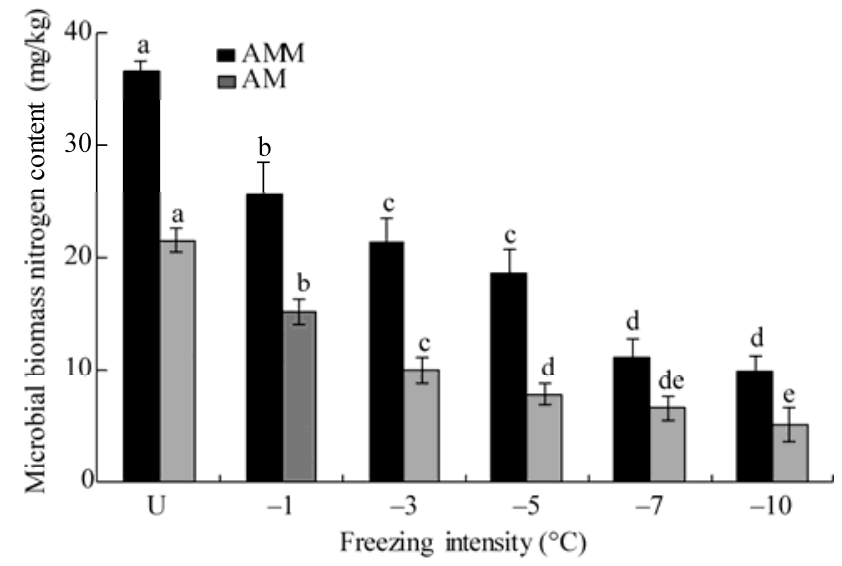

Fig. 1 Effect of freezing intensity on the microbial biomass nitrogen content. Values of each ecosystem type followed by different letters indicate significant difference at the $P<0.05$ level. U, a constant temperature of $11^{\circ} \mathrm{C}$ treatment. AMM, alpine marsh meadow; AM, alpine meadow. The abbreviations are the same.

\subsection{Effect of freezing intensity on DON content}

After the freeze-thaw treatment at $-10^{\circ} \mathrm{C}$, the soil $\mathrm{DON}$ content of alpine marsh meadow 
increased by $43.25 \mathrm{mg} / \mathrm{kg}$ and that of the alpine meadow increased by $11.14 \mathrm{mg} / \mathrm{kg}$ (Fig. 2). After the freeze-thaw treatments, the soil DON content of alpine grassland ecosystem on the Tibetan Plateau all increased significantly compared with those of untreated soil samples. After freeze-thaw treatments at $-7^{\circ} \mathrm{C}$ and $-10^{\circ} \mathrm{C}$, there was no significant difference between the soil DON content of alpine meadow while the difference was significant at other freezing temperatures. For alpine marsh meadow, the soil DON content did not significantly increase after freeze-thaw treatment at $-1^{\circ} \mathrm{C}$, while it significantly differed at other freezing temperatures.

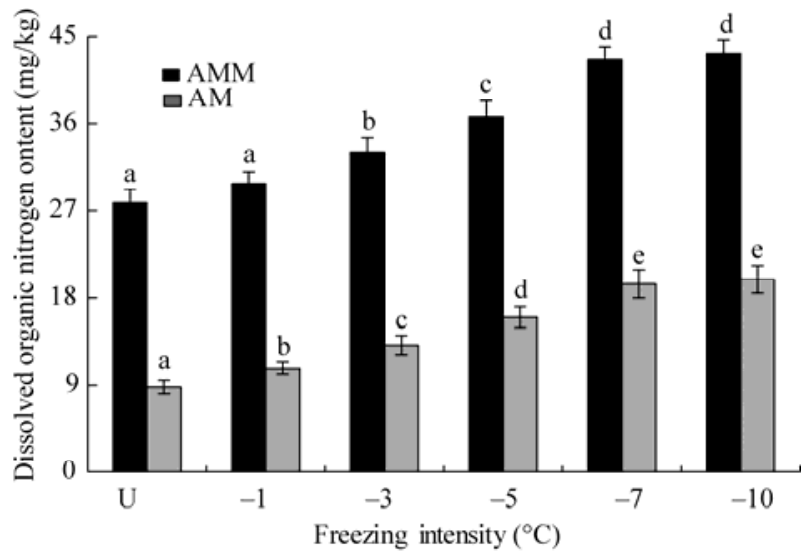

Fig. 2 Effect of freezing intensity on dissolved organic nitrogen content. Values of each ecosystem type followed by different letters indicate significant difference at the $P<0.05$ level.

\subsection{Effect of freezing intensity on inorganic nitrogen content}

Soil $\mathrm{N}_{-\mathrm{NH}_{4}}{ }^{+}$content of alpine marsh meadow was $15.88 \mathrm{mg} / \mathrm{kg}$ in untreated soil and it significantly increased after the freeze-thaw treatment. The $\mathrm{N}^{-\mathrm{NH}_{4}}{ }^{+}$content increased by 9.97 $\mathrm{mg} / \mathrm{kg}$ after freeze-thaw treatment at $-1{ }^{\circ} \mathrm{C}$ and reaching $41.43 \mathrm{mg} / \mathrm{kg}$ after freeze-thaw treatment at $-10^{\circ} \mathrm{C}$. There was no obvious difference between the ${\mathrm{N}-\mathrm{NH}_{4}}^{+}$content at $-7^{\circ} \mathrm{C}$ and $-10^{\circ} \mathrm{C}$ freezing temperatures, while the $\mathrm{N}_{-} \mathrm{NH}_{4}{ }^{+}$content greatly differed at other freezing temperatures (Fig. 3). For the alpine meadow, the $\mathrm{N}^{4} \mathrm{NH}_{4}{ }^{+}$content greatly differed at $-1^{\circ} \mathrm{C}$ and $-3^{\circ} \mathrm{C}$ freezing temperatures compared with those at other freezing temperatures, and there was no difference between the $\mathrm{N}^{-\mathrm{NH}_{4}}{ }^{+}$contents at other temperatures.
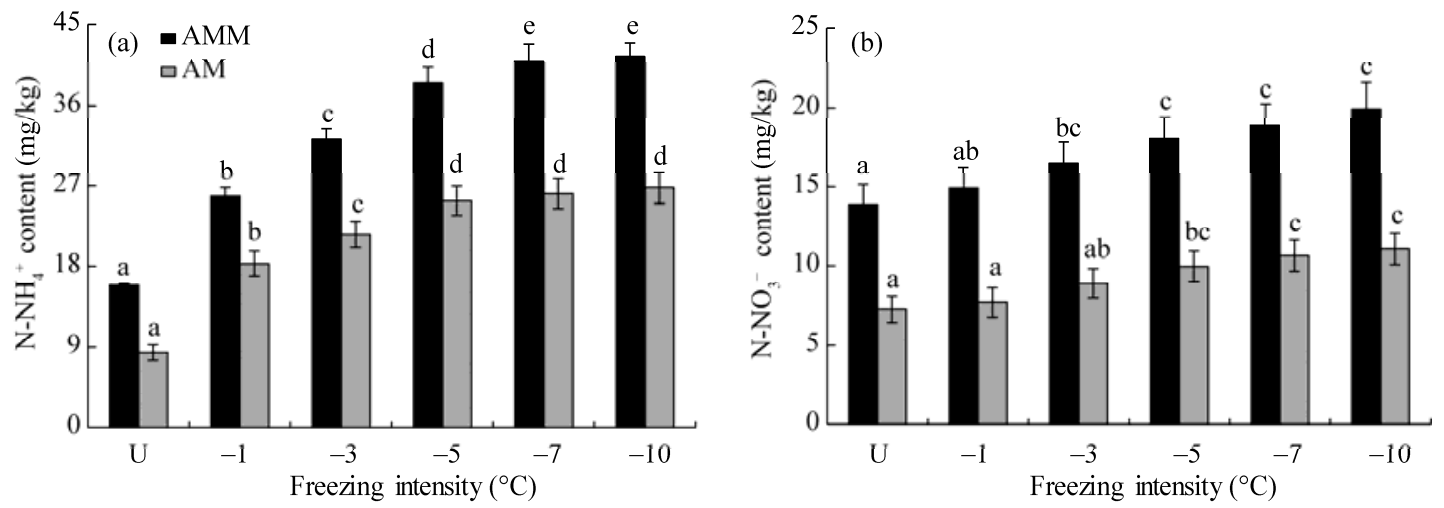

Fig. 3 Effect of freezing intensity on $\mathrm{N}_{-} \mathrm{NH}_{4}{ }^{+}$and $\mathrm{N}_{-} \mathrm{NO}_{3}{ }^{-}$contents. Values of each ecosystem type followed by different letters indicate significant difference at the $P<0.05$ level.

Soil $\mathrm{N}_{-} \mathrm{NO}_{3}{ }^{-}$content increased during the freeze-thaw treatment, but the increase range was less than that of the $\mathrm{N}^{-\mathrm{NH}_{4}}{ }^{+}$content. The $\mathrm{N}^{-\mathrm{NO}_{3}}{ }^{-}$contents of alpine marsh meadow and alpine meadow were 14.85 and $11.07 \mathrm{mg} / \mathrm{kg}$, respectively, after freeze-thaw treatment at $-10^{\circ} \mathrm{C}$, which increased by 1.43 and 1.53 times, respectively (Fig. 3). The LSD test indicated that soil $\mathrm{N}_{-} \mathrm{NO}_{3}{ }^{-}$ content of alpine meadow did not increase significantly during the $-1{ }^{\circ} \mathrm{C}$ and $-3^{\circ} \mathrm{C}$ freeze-thaw 
temperatures and there was no significant difference between soil $\mathrm{N}^{-\mathrm{NO}_{3}}{ }^{-}$contents of alpine meadow at the freezing temperatures of $-5^{\circ} \mathrm{C}$ to $-10^{\circ} \mathrm{C}$. For alpine marsh meadow, there was no significant difference between the soil $\mathrm{N}^{-N}{ }_{3}{ }^{-}$contents at the freezing temperatures of $-3^{\circ} \mathrm{C}$ to $-10^{\circ} \mathrm{C}$, but it increased significantly compared with untreated soil samples and at the freezing temperature of $-1{ }^{\circ} \mathrm{C}$, and there was no difference between the soil $\mathrm{N}_{-} \mathrm{NO}_{3}{ }^{-}$content in untreated samples and at the $-1^{\circ} \mathrm{C}$ freezing temperature.

\section{Discussion}

The impact of the freeze-thaw process on the MBN content is influenced by the comprehensive effects of various factors like freeze-thaw rate, freezing strength, freeze-thaw frequency, vegetation coverage and soil texture (Edwards and Cresser, 1992), thus resulting in significant differences in the MBN content response to the freeze-thaw process in different areas. Schimel et al. (1996) indicated that the alternation of freezing and thawing has a killing effect on micro-organisms, namely, reduces the amount of soil micro-organisms and kills micro-organisms, which is similar to the alternation of drying and wetting or chloroform fumigation. Walker et al. (2006) believed that the soil MBN content significantly decreased and then slightly increased in the first few freeze-thaw cycles. This study indicated that the freeze-thaw process had a significant influence on the soil MBN content of alpine grassland (Fig. 1) and the MBN content decreased by $38.81 \%-41.38 \%$ after once freeze-thaw treatement compared with untreated soil samples (Table 2). Xu et al. (2011) studied the influence of the freeze-thaw process on the soil MBN content of alpine meadows, and the results showed that after once freeze-thaw treatment, the soil MBN content decreased by $57.47 \%, 37.79 \%$ and $37.51 \%$, respectively after freeze-thaw treatments at $-4^{\circ} \mathrm{C},-4^{\circ} \mathrm{C}$ to $4^{\circ} \mathrm{C}$ and $-20^{\circ} \mathrm{C}$ to $4^{\circ} \mathrm{C}$, which is consistent with the results obtained in this study. This showed that after freeze-thaw, the MBN content of alpine grassland ecosystems on the Tibetan Plateau significantly decreased. In this study, all MBN content after the freeze-thaw treatment showed a significantly decreasing trend compared with those in untreated soil samples, which indicated that the freezing temperature was an important factor affecting the MBN content of alpine grassland ecosystems of the Tibetan Plateau. Soil MBN of alpine meadow in response to the freeze-thaw process indicates that the main reason for the MBN change might be the freeze-thaw time instead of freezing temperature (Xu et al., 2011). The differences of the research results further indicate the complexity of the micro-organisms in response to the freeze-thaw process.

Table 2 The percentage (\%) of nitrogen component variation at each freezing temperature to its total difference

\begin{tabular}{clccccc}
\hline & $-1{ }^{\circ} \mathrm{C}$ to $\mathrm{U}$ & $-3^{\circ} \mathrm{C}$ to $-1{ }^{\circ} \mathrm{C}$ & $-5^{\circ} \mathrm{C}$ to $-3^{\circ} \mathrm{C}$ & $-7^{\circ} \mathrm{C}$ to $-5^{\circ} \mathrm{C}$ & $-10^{\circ} \mathrm{C}$ to $-7^{\circ} \mathrm{C}$ \\
\hline \multirow{2}{*}{$\mathrm{AMM}$} & 41.38 & 15.73 & 10.33 & 27.93 & 4.64 \\
& $\mathrm{MBN}$ & 12.86 & 21.31 & 23.56 & 38.85 & 3.42 \\
& $\mathrm{DON}$ & 39.01 & 24.93 & 24.46 & 9.63 & 1.97 \\
& $\mathrm{~N}^{-N_{4}}{ }^{+}$ & 17.02 & 26.41 & 25.64 & 13.65 & 17.29 \\
& $\mathrm{~N}^{-}$ & 38.81 & 31.70 & 13.26 & 7.35 & 8.87 \\
& $\mathrm{MBN}$ & 18.14 & 21.38 & 25.60 & 30.78 & 4.10 \\
$\mathrm{AM}$ & $\mathrm{NON}$ & 53.75 & 17.68 & 20.59 & 4.33 & 3.66 \\
& $\mathrm{~N}-\mathrm{NH}_{4}{ }^{+}$ & 11.61 & 31.15 & 27.92 & 18.24 & 11.08 \\
\hline
\end{tabular}

Note: AMM, alpine marsh meadow; AM, alpine meadow; MBN, microbial biomass nitrogen; DON, dissolved organic nitrogen; U, a constant temperature of $11^{\circ} \mathrm{C}$ treatment.

DON, which is the direct or potential nitrogen source absorbed and utilized by the soil micro-organisms and plants, has an important influence on the soil nitrogen availability (Smith et al., 1998; Zhong and Makeschin, 2003). In this study, the soil DON content of the alpine grassland ecosystem was $8.81-27.83 \mathrm{mg} / \mathrm{kg}$ and the freeze-thaw significantly increased soil DON content. Freeze-thaw action kills micro-organisms; meanwhile, the amino acid nitrogen mainly in 
microbial cells is released with the decomposition of dead micro-organisms, thereby resulting in an increase in the soil DON content (Wang and Bettany, 1993). In this study, there was a significant negative correlation between MBN and DON $(P<0.05)$ (Fig. 4), indicating that MBN is an important source for the increase of the alpine grassland soil DON after freeze-thaw action. Soil aggregate is an important factor determining the soil DON content (Lehrsch et al., 1991). When soil freezes, the expansion of ice crystals in soil pores breaks the link between soil particles, changes the size and stability of the soil aggregates and leads to an increase in the trend of breaking big soil aggregates into small ones, and the lower freezing temperature leads to fewer stable soil aggregates (Lehrsch et al., 1991). The freeze-thaw damage to the stability of soil aggregates releases small molecules that are trapped and adsorbed by soil, which might be one of the possible causes of the increase of soil DON content in the alpine grassland with increase of the freezing intensity in this study (Lehrsch et al., 1991; Grogan et al., 2004).

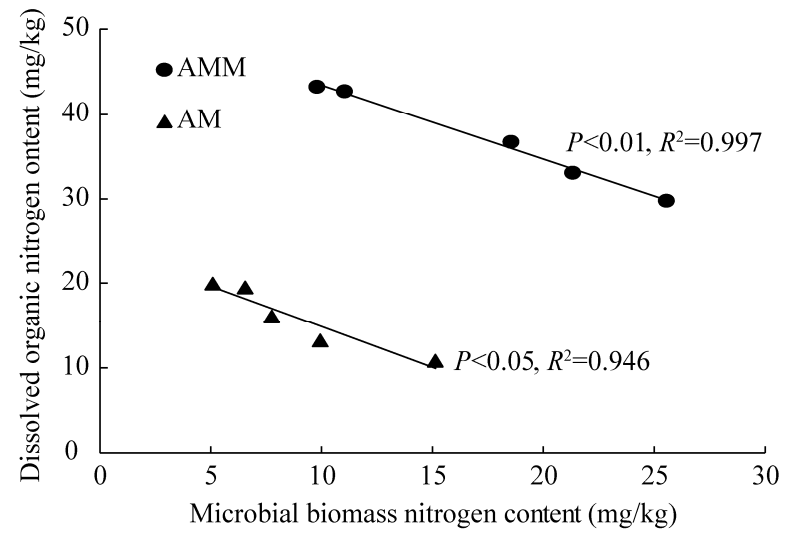

Fig. 4 Correlation between microbial biomass nitrogen and dissolved organic nitrogen

Freeze-thaw action led to an increase in the concentrations of $\mathrm{N}_{-} \mathrm{NH}_{4}{ }^{+}$and $\mathrm{N}_{-} \mathrm{NO}_{3}{ }^{-}$, and the lower the freezing temperature, the more the accumulative contents of $\mathrm{N}^{-\mathrm{NH}_{4}}{ }^{+}$and $\mathrm{N}-\mathrm{NO}_{3}{ }^{-}$, which indicated that freeze-thaw action had promoted the soil nitrogen mineralization of the alpine grassland ecosystem on the Tibetan Plateau. The increase of soil inorganic nitrogen may result from the following mechanism, namely, the release of inorganic nitrogen comes directly from the soil micro-organisms after they are killed partly during the freeze-thaw process and their cells rupture (DeLuca et al., 1992). Second, as the dead micro-organisms provide the remaining micro-organisms with enough matrixes and stimulate their activities, it is beneficial to the mineralization process of the soil organic nitrogen (Herrmann and Witter, 2002). The freeze-thaw damage to the soil aggregates released the inactive $\mathrm{NH}_{4}{ }^{+}$into the organic matter and inorganic

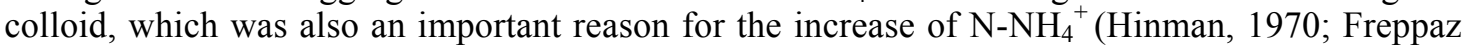

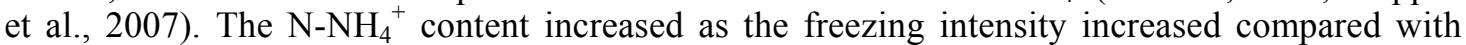
untreated soil samples. The existing studies also showed that the impact of severe freezing temperature on $\mathrm{N}_{-} \mathrm{NH}_{4}{ }^{+}$content was more obvious (Xu et al., 2011). Under different freeze-thaw treatment, the soil mineralized nitrogen was mainly the ${\mathrm{N}-\mathrm{NH}_{4}}^{+}$, which had a certain correlation with the decrease in the soil $\mathrm{N}_{-N_{3}}{ }^{-}$content due to the freeze-thaw action (Nielsen et al., 2001; Grogan et al., 2004). Although the freeze-thaw process increased the $\mathrm{N}_{-} \mathrm{NH}_{4}{ }^{+}$content and soil nitrification substrates, the nitration reaction was weakened because the autotrophic nitrifying bacteria were sensitive to the environmental change and recover slowly (Nielsen et al., 2001). The freeze-thaw process can enhance the denitrification process and promote $\mathrm{N}_{2} \mathrm{O}$ emission, thus resulting in the denitrification process being stronger than the nitrification process, which is not advantageous for $\mathrm{N}_{-} \mathrm{NO}_{3}{ }^{-}$accumulation. In this study, the soil $\mathrm{DON}, \mathrm{N}_{-} \mathrm{NH}_{4}{ }^{+}$and $\mathrm{N}-\mathrm{NO}_{3}{ }^{-}$ contents of the alpine grassland of the Tibetan Plateau increased due to the freeze-thaw action, which indicated that the freeze-thaw increased soil total soluble nitrogen content. Although the total soluble nitrogen increased, the percentage contribution of the nitrate nitrogen remained unchanged or slightly decreased (Fig. 5), which indicated that the freeze-thaw action caused the loss of soil nitrogen of alpine grassland from the system. 
(a) $=\mathrm{N}-\mathrm{NO}_{3}^{-} / \mathrm{TDN}=\mathrm{N}-\mathrm{NH}_{4}^{+} / \mathrm{TDN}=\mathrm{DON} / \mathrm{TDN}$

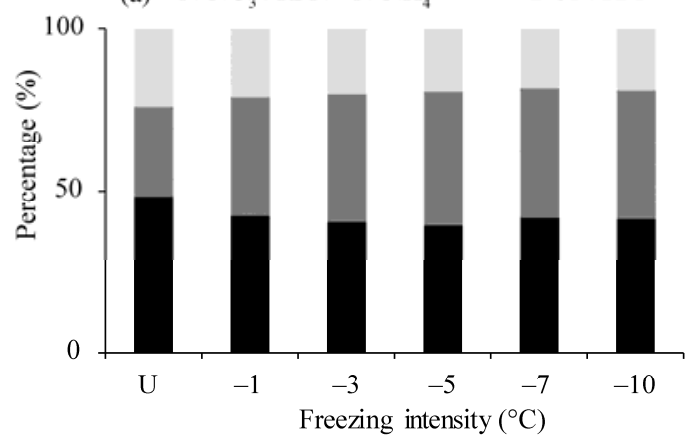

(b)

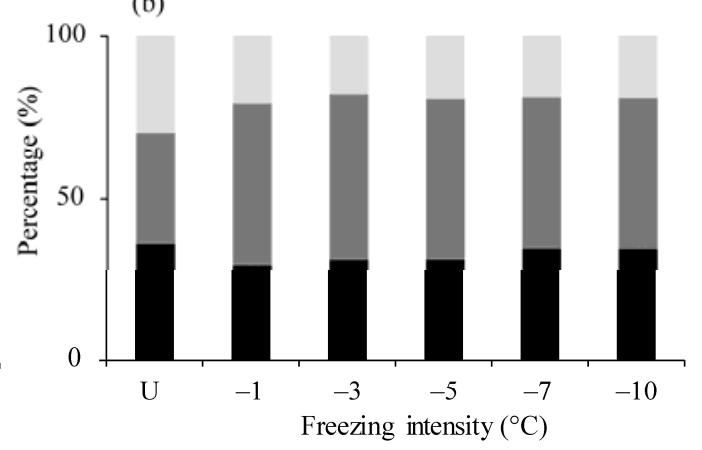

Fig. 5 Percentage contribution of $\mathrm{N}_{-} \mathrm{NO}_{3}{ }^{-}, \mathrm{N}^{-\mathrm{NH}_{4}}{ }^{+}$and dissolved organic nitrogen (DON) to the total dissolved nitrogen (TDN). (a), alpine marsh meadow; (b), alpine meadow.

Studies showed that different freezing intensity had a significant impact on soil nitrogen components of alpine grassland ecosystem on the Tibetan Plateau. The content variations of each nitrogen component at different freezing temperatures showed differences. By analyzing these variations, we found that the soil MBN contents of alpine grassland decreased while the DON and inorganic nitrogen contents increased with the increase of the freezing strength in general. When the freezing temperature was below $-7^{\circ} \mathrm{C}$, there was no significant difference between the contents of each nitrogen component. Studies have shown that the nitrogen mineralization capacity of Norway spruce forest soil significantly decreased after freezing treatments at $-3^{\circ} \mathrm{C}$, $-8^{\circ} \mathrm{C}$ and $-13^{\circ} \mathrm{C}$ compared with that without the freezing treatment (Hentschel et al., 2008). The freezing treatments at $-8^{\circ} \mathrm{C}$ and $-13^{\circ} \mathrm{C}$ had the strongest impact on the soil nitrogen mineralization, but there was no difference between the two treatments (Goldberg et al., 2008), which had similarity with the results of this study. It is thereby inferred that the change of soil microbial communities and each nitrogen component may have a response threshold toward freezing temperature, and when the temperature is below this threshold the microbial biomass and each nitrogen component do not change significantly with decreasing temperature. There was no significant difference between the soil nitrogen mineralization of Norway spruce forest after freezing treatment at $-8^{\circ} \mathrm{C}$ and in this study there was no significant difference between the contents of each nitrogen component of alpine grassland soil when the temperature was below $-7^{\circ} \mathrm{C}$, thereby indicating that the response threshold of soil microbial communities and each nitrogen component toward freezing temperature was relevant to a specific soil, which was perhaps relevant to the climate of each sampling site. For alpine marsh meadow soil, there was no significant difference between the soil $\mathrm{N}_{-} \mathrm{NH}_{4}{ }^{+}$contents after freezing treatments at $-7^{\circ} \mathrm{C}$ and $-10^{\circ} \mathrm{C}$, while there was a significant difference between the soil $\mathrm{N}-\mathrm{NH}_{4}{ }^{+}$contents after freezing treatments at $-7^{\circ} \mathrm{C}$ and $-5^{\circ} \mathrm{C}$. However, for alpine meadow soil, there was no significant difference between the soil $\mathrm{N}-\mathrm{NH}_{4}{ }^{+}$contents after freezing treatment at $-5^{\circ} \mathrm{C},-7^{\circ} \mathrm{C}$ and $-10^{\circ} \mathrm{C}$. The response differences of soil $\mathrm{N}_{-} \mathrm{NH}_{4}{ }^{+}$contents of the alpine marsh meadow and alpine grassland toward freezing temperature indicated that even when the soil samples were collected from the same climate zone with the same local climate conditions, their response thresholds showed a difference. This difference may be mainly caused by the difference of soil water content, organic matter content, mechanical composition and other physical and chemical properties. Whether the response threshold of the soil nitrogen process of different vegetation types toward freezing intensity has universality and its influence factors need to be further studied.

The freeze-thaw process can increase the grassland community productivity in the next growing season (Kreyling et al., 2008, 2010) and further influence the ecosystem stability and services (Kreyling et al., 2008). The area of this study is located in a large continuous permafrost zone of the Tibetan Plateau and the permafrost, as a widespread aquiclude, can effectively prevent the infiltration and migration of the surface soil moisture, make the vegetation root layer maintain high moisture and force various leached nutrients at the active layer to gather here ( $\mathrm{Li}$ et al., 
2005). The freeze-thaw process significantly increased the soil DON and inorganic nitrogen contents. Along with the thaw of the active layer, the increased soluble nitrogen in the soil migrates to the top of the permafrost layer with the soil moisture, which provides nutrients for the growth of plants in the early growing season. Therefore, the increase of the soluble nitrogen content in soil caused by freeze-thaw action had an important impact on the originally nitrogen-limited alpine grassland ecosystems in the permafrost region of the Tibetan Plateau. As a product of climatic conditions, the permafrost is extremely sensitive to climate change (Wu et al., 2003). The regional temperature increase has already led to widespread degradation, thickness decrease or partial area's disappearance of permafrost (Cheng and $\mathrm{Wu}, 2007$ ). The permafrost degradation will make the nutrients accumulated in the upper part of the permafrost further migrate downwards with the increase of active layer thickness and thus lead to plants failing to utilize these nutrients. In this case, the freeze-thaw action may increase the soil nitrogen leaching losses risk to alpine grassland in the permafrost region of the Tibetan Plateau.

\section{Conclusions}

This study explored the influence of freezing intensity on soil nitrogen components of alpine grassland on the Tibetan Plateau. The results demonstrated that the freezing process had a significant impact on the soil MBN content of alpine grassland $(P<0.05)$ and the MBN content decreased by $38.81 \%-41.38 \%$ after freeze-thaw treatments compared with untreated soil samples. The soil DON content of the alpine grassland ecosystem was $8.81-27.83 \mathrm{mg} / \mathrm{kg}$ and freeze-thaw action markedly increased the soil DON content while the MBN was an important source of the soil DON increase of alpine grassland on the Tibetan Plateau. Under different freeze-thaw treatments, the soil mineralized nitrogen was mainly the $\mathrm{N}_{-} \mathrm{NH}_{4}{ }^{+}$. The freeze-thaw action led to an increase in the concentrations of $\mathrm{N}_{-} \mathrm{NH}_{4}{ }^{+}$and $\mathrm{N}_{-} \mathrm{NO}_{3}{ }^{-}$, and the lower the freezing temperature, the more the accumulative contents of $\mathrm{N}_{-} \mathrm{NH}_{4}{ }^{+}$and $\mathrm{N}_{-} \mathrm{NO}_{3}{ }^{-}$. When the freezing temperature was below $-7^{\circ} \mathrm{C}$, there was no significant difference between the contents of each nitrogen component, which implied that the changes of soil microbial communities and each nitrogen component might have a response threshold toward freezing temperature. We suggest that in future studies an in situ study should be carried out in the months when the Tibetan Plateau soil alters from freezing to thawing. Through comparison of the in situ study with experimental simulation results, we will gain insight into the mechanism of how freeze-thaw action influences the soil nitrogen process of the alpine grassland ecosystems on the Tibetan Plateau.

\section{Acknowledgments}

This study was funded by the National Natural Science Foundation of China (31100337) and the Scientific Research Foundation of Nanjing University of Information Science \& Technology (2243141301132). We are grateful to anonymous reviewers for their valuable comments on earlier versions of the manuscript.

\section{References}

Brookes P C, Landman A, Pruden G, et al. 1985. Chloroform fumigation and the release of soil nitrogen: a rapid direct extraction method to measure microbial biomass nitrogen in soil. Soil Biology and Biochemistry, 17(6): 837-842.

Brooks P D, Williams M W. 1999. Snowpack controls on nitrogen cycling and export in seasonally snow-covered catchments. Hydrological Processes, 13(14-15): 2177-2190.

Campbell J L, Mitchell M J, Groffman P M, et al. 2005. Winter in northeastern North America: a critical period for ecological processes. Frontiers in Ecology and the Environment, 3(6): 314-322.

Chang C, Hao X. 2001. Source of $\mathrm{N}_{2} \mathrm{O}$ emission from a soil during freezing and thawing. Phyton (Austria), 41(3): 49-60.

Chen Y, Tessier S, MacKensie A F, et al. 1995. Nitrous oxide emission from an agricultural soil subjected to different freeze-thaw cycles. Agriculture, Ecosystems \& Environment, 55(2): 123-128.

Cheng G D, Wu T H. 2007. Responses of permafrost to climate change and their environmental significance, Qinghai-Tibet Plateau. Journal of Geophysical Research, 112(F2): F02S03, doi: 10.1029/2006JF000631. 
DeLuca T H, Keeney D R, McCarty G W. 1992. Effect of freeze-thaw events on mineralization of soil nitrogen. Biology and Fertility of Soils, 14(2): 116-120.

Dong Z B, Hu G Y, Yan C Z, et al. 2010. Aeolian desertification and its causes in the Zoige Plateau of China's Qinghai-Tibetan Plateau. Environmental Earth Sciences, 59(8): 1731-1740.

Easterling D R, Meehl G A, Parmesan C, et al. 2000. Climate extremes: observations, modeling, and impacts. Science, 289(5487): 2068-2074.

Edwards A C, Cresser M S. 1992. Freezing and its effect on chemical and biological properties of soil. In: Stewart B A. Advances in Soil Science. New York: Springer, 59-79.

Freppaz M, Williams B L, Edwards A C, et al. 2007. Simulating soil freeze/thaw cycles typical of winter alpine conditions: implications for $\mathrm{N}$ and $\mathrm{P}$ availability. Applied Soil Ecology, 35(1): 247-255.

Goldberg S D, Muhr J, Borken W, et al. 2008. Fluxes of climate-relevant trace gases between a Norway spruce forest soil and atmosphere during repeated freeze-thaw cycles in mesocosms. Journal of Plant Nutrition and Soil Science, 171(5): 729-739.

Grogan P, Jonasson S. 2003. Controls on annual nitrogen cycling in the understory of a subarctic birch forest. Ecology, 84(1): $202-218$

Grogan P, Michelsen A, Ambus P, et al. 2004. Freeze-thaw regime effects on carbon and nitrogen dynamics in sub-arctic heath tundra mesocosms. Soil Biology and Biochemistry, 36(4): 641-654.

Henry H A L. 2008. Climate change and soil freezing dynamics: historical trends and projected changes. Climatic Change, 87(3-4): 421-434.

Hentschel K, Borken W, Matzner E. 2008. Repeated freeze-thaw events affect leaching losses of nitrogen and dissolved organic matter in a forest soil. Journal of Plant Nutrition and Soil Science, 171(5): 699-706.

Herrmann A, Witter E. 2002. Sources of C and N contributing to the flush in mineralization upon freeze-thaw cycles in soils. Soil Biology and Biochemistry, 34(10): 1495-1505.

Hinman W C. 1970. Effects of freezing and thawing on some chemical properties of three soils. Canadian Journal of Soil Science, 50(2): 179-182.

IPCC. 2007. Climate Change 2007: Synthesis Report. Contribution of Working Groups I, II and III to the Fourth Assessment Report of the Intergovernmental Panel on Climate Change. Geneva, Switzerland: IPCC.

Isard S A, Schaetzl R J. 1998. Effects of winter weather conditions on soil freezing in southern Michigan. Physical Geography, 19(1): 71-94.

Kaste Ø, Austnes K, Vestgarden L S, et al. 2008. Manipulation of snow in small headwater catchments at Storgama, Norway: effects on leaching of inorganic nitrogen. AMBIO: A Journal of the Human Environment, 37(1): $29-37$.

Kielland K, Olson K, Ruess R W, et al. 2006. Contribution of winter processes to soil nitrogen flux in taiga forest ecosystems. Biogeochemistry, 81(3): 349-360.

Kreyling J, Beierkuhnlein C, Pritsch K, et al. 2008. Recurrent soil freeze-thaw cycles enhance grassland productivity. New Phytologist, 177(4): 938-945.

Kreyling J, Beierkuhnlein C, Jentsch A. 2010. Effects of soil freeze-thaw cycles differ between experimental plant communities. Basic and Applied Ecology, 11(1): 65-75.

Lehrsch G A, Sojka R E, Carter D L, et al. 1991. Freezing effects on aggregate stability affected by texture, mineralogy, and organic matter. Soil Science Society of America Journal, 55(5): 1401-1406.

Li N, Wang G X, Gao Y H, et al. 2010. Effects of simulated warming on soil nutrients and biological characteristics of alpine meadow soil in the headwaters region of the Yangtze River. Acta Pedologica Sinica, 47(6): 1214-1224. (in Chinese)

Li Y N, Guan D G, Zhao L, et al. 2005. Seasonal frozen soil and its effect on vegetation production in Haibei alpine meadow. Journal of Glaciology and Geocryology, 27(3): 311-319. (in Chinese)

Lipson D A, Schmidt S K. 2004. Seasonal changes in an alpine soil bacterial community in the Colorado Rocky Mountains. Applied and Environmental Microbiology, 70(5): 2867-2879.

Liu J Y, Xu X L, Shao Q Q. 2008. Grassland degradation in the "Three-River Headwaters" region, Qinghai Province. Journal of Geographical Sciences, 18(3): 259-273.

Liu X D, Chen B D. 2000. Climatic warming in the Tibetan Plateau during recent decades. International Journal of Climatology, 20(14): 1729-1742.

Mellander P E, Löfvenius M O, Laudon H. 2007. Climate change impact on snow and soil temperature in boreal Scots pine stands. Climatic Change, 85(1-2): 179-193.

Monson R K, Lipson D L, Burns S P, et al. 2006. Winter forest soil respiration controlled by climate and microbial community composition. Nature, 439(7077): 711-714.

Nielsen C B, Groffman P M, Hamburg S P, et al. 2001. Freezing effects on carbon and nitrogen cycling in northern hardwood 
forest Soils. Soil Science Society of America Journal, 65(6): 1723-1730.

Panikov N S, Flanagan P W, Oechel W C, et al. 2006. Microbial activity in soils frozen to below $-39^{\circ} \mathrm{C}$. Soil Biology and Biochemistry, 38(4): 785-794.

Ron Vaz M D, Edwards A C, Shand C A, et al. 1994. Changes in the chemistry of soil solution and acetic-acid extractable P following different types of freeze/thaw episodes. European Journal of Soil Science, 45(3): 353-359.

Schadt C W, Martin A P, Lipson D A, et al. 2003. Seasonal dynamics of previously unknown fungal lineages in tundra soils. Science, 301(5638): 1359-1361.

Schimel J P, Clein J S. 1996. Microbial response to freeze-thaw cycles in tundra and taiga soils. Soil Biology and Biochemistry, 28(8): 1061-1066.

Six J, Bossuyt H, Degryze S, et al. 2004. A history of research on the link between (micro) aggregates, soil biota, and soil organic matter dynamics. Soil and Tillage Research, 79(1): 7-31.

Sjursen H, Michelsen A, Holmstrup M. 2005. Effects of freeze- thaw cycles and thawing on Microarthropods and nutrient availability in a sub-arctic soil. Applied Soil Ecology, 28(1): 79-93.

Smith C K, Munson A D, Coyea M R. 1998. Nitrogen and phosphorus release from humus and mineral soil under black spruce forests in central Quebec. Soil Biology and Biochemistry, 30(12): 1491-1500.

Walker V K, Palmer G R, Voordouw G. 2006. Freeze-thaw tolerance and clues to the winter survival of a soil community. Applied and Environmental Microbiology, 72(3): 1784-1792.

Wang F L, Bettany J R. 1993. Influence of freeze-thaw and flooding on the loss of soluble organic carbon and carbon dioxide from soil. Journal of Environmental Quality, 22(4): 709-714.

Wu Q H, Shi B, Liu Y Z. 2003. Interaction study of permafrost and highway along Qinghai-Xizang Highway. Science in China Series D: Earth Sciences, 46(2): 97-105.

Xu J J, Wu Y, Zhang X Q, et al. 2011. Effects of freezing and thawing cycles on microbial biomass nitrogen and organic nitrogen in alpine meadow soil. Chinese Journal of Applied \& Environmental Biology, 17(1): 57-62. (in Chinese)

Yang R, Zhao M X, Zhou J B. 2005. Effects of different conditions on the determination of total nitrogen in solution by persulfate oxidation method. Journal of Northwest Science-Technology University of Agriculture and Forest (Nature Science Edition), 33(12): 107-111. (in Chinese)

Yang R, Yan D Y, Zhou J B, et al. 2007. Soluble organic nitrogen (SON) in different soils on the loess Plateau of China. Acta Ecologica Sinica, 27(4): 1397-1403. (in Chinese)

Zhong Z K, Makeschin F. 2003. Soluble organic nitrogen in temperate forest soils. Soil Biology and Biochemistry, 35(2): 333-338. 